\title{
External Morphological Characteristics for Histogenesis in Pecan Anthers
}

\author{
I.E. Yates \\ Russell Research Center, Agricultural Research Service, U.S. Department of Agriculture, Athens, \\ GA 30613
}

\section{Darrell Sparks}

Department of Horticulture, University of Georgia, Athens, GA 30602

Additional index words. Carya illinoensis, staminate flower, pollen, bracts, bracteoles, electron microscopy

\begin{abstract}
External "morphological characteristics of catkins from one protogynous ('Stuart') and one protandrous ('Desirable') cultivar of pecan [Carya illinoensis Wangenh.) C. Koch] were examined to define markers of cellular differentiation in the anthers. The angle between the catkin rachis and the bract, visibility of the bracteole, rachis, and anther, and anther color proved to be markers by which development could be categorized into five stages. 'Stuart' catkins with bracts as the only externally visible portion of the floret (Stage I) commonly had two locules in each anther lobe. When bracteoles became externally visible (Stage II), cellular specialization had occurred to form a central core containing reproductive cells and tapetal cells differentiated and separated from the exterior layers of the anther wall. Disintegration of tapetal cells and thickening of endothecium eel! walls occurred as the angle between the rachis and bract increased to $45^{\circ}$ (Stage III). The anther wall was reduced to only two cell layers, epidermis and endothecium, as the anthers became visible (Stage IV). The pollen grains were mature when the anthers developed a yellowish tinge (Stage V) just before anther dehiscence. Tapetal cells had developed distinguishing traits in anthers of Stage I 'Desirable' catkins and endothecial cells of Stage II. Internal anther development was similar for both cultivars from Stages III-V. Trichomes, a common feature-on the surface of the staminate floral parts, became less dense with proximity of the floral parts to the interior of the floret and with catkin maturity.
\end{abstract}

The anatomy and morphology of the pecan staminate inflorescence from the time of initiation until budbreak have been studied by several investigators (Haulik, 1985; Haulik and Holtzhausen, 1988; Maximos et al., 1984; Wetzstein and Sparks, 1984; Woodroof, 1930). A consensus among these studies is that development of the pecan staminate inflorescence requires $\approx 1$ year from the time of initiation to maturation. The growing season during which cultivars initiate some parts of the staminate flower varies with the dichogamy pattern (Wetzstein and Sparks, 1984; Woodroof, 1930). Protandrous cultivars initiate the floral apex, bracteoles, and anther primordia during the growing season of the year before pollen maturation, whereas protogynous cultivars do. not initiate these floral parts until the growing season in which the pollen reaches maturation. Development of bilobate anthers occurs in the growing season in which the pollen reaches maturation, regardless of dichogamy pattern.

Catkin development from the stage of the bilobate anther, which coincides with budbreak (Haulik, 1985), until anther dehiscence requires $\approx 30$ days (Davis and Sparks, 1971). Woodroof (1930) described differentiation of the anther wall and microsporangia during this phase of catkin development. However, the events were cataloged on a temporal sequence relative to the number of days before pollen shed. The difficulty of such an assessment is that the marker (pollen shed) occurs after the differentiation being traced. Hence, the time of pollen shed must be projected to judge histogenesis in the anther. Attempting to project a marker event is further confounded because timing of

Received for publication 25 Jan. 1991. The assistance of Donnie Maxey and Joyce Lambert in the preparation of photomicrographs is gratefully acknowledged. Trade names are used in this publication to provide specific information. Mention of a trade name does not constitute a guarantee or warranty of the product or an endorsement by the USDA over other products not mentioned. The cost of publishing this paper was defrayed in part by the payment of page charges. Under postal regulations, this paper therefore must be hereby marked advertisement solely to indicate this fact. development in pecan can vary from year to year (Sparks, 1989) or from cultivar to cultivar (Nakayama, 1967). Marker characteristics should be linked genetically to the differentiation process to be stable in spite of climatic variations. Markers that are easily duplicated and measured can be used to readily identify the dynamic events of anther histogenesis and allow more meaningful comparisons among studies. Characters used as markers to judge differentiation at the cellular level should be microscopically visible for a field-grown plant, such as a pecan tree. Thus, cellular specialization can be estimated before collection without transporting laboratory equipment to the field, or, alternatively, field samples to the laboratory for examination of tissues.

Morphological characters have been identified in other plant species as indicators of developmental stage. Caryopsis development in Triticum aestivum L. has been defined using grain color and size, embryo length, and characteristics of endosperm and pericarp (Rogers and Quatrano, 1983). The distance of flag leaf emergence is a reliable indicator of the stage of microspore development in Hordeum vulgare L. (Wheatley et al., 1986). The relationship between the external morphology of the pecan catkin and cellular specialization in the anther has not been established even though the anatomy of staminate flower differentiation has been studied extensively (Haulik, 1985; Haulik and Holtzhausen, 1988; Maximos et al., 1984; Wetzstein and Sparks, 1984; Woodroof, 1930). Preliminary evidence indicated that classifying pecan catkin differentiation into three stages based on the position of the bracts relative to the rachis reflected the period of microsporogenesis and pollen differentiation (Cope and Yates, 1987; Yates et al., 1986). The objective of our study was to determine whether a combination of morphological features of catkins could be used to predict histogenesis in the anthers.

\section{Materials and Methods}

Plant material. Catkins were sampled from the time the stareinate inflorescence became extended beyond the bud scales and 
continued until anther dehiscence from four trees each of a protandrous ('Desirable') and a protogynous ('Stuart') cultivar, growing at the Univ. of Georgia Horticulture Farm, Watkinsville. The middle catkin of the three-pronged inflorescence was collected from five staminate inflorescences from each tree for each collection of a given stage (Table 1) of catkin morphology. Catkin morphology was based on the appearance of florets located at the midpoint of the catkin length. At least two stages of catkin morphology could be identified at any given collection date on the trees designated for sampling (Table 2). Four stages of development were harvested on each collection date from 26 Apr. to 2. May 1990 for 'Stuart'. Most stages were collected over a span of several days, i.e., there was a range of 9 days for 'Desirable' and 11 days for 'Stuart' for which Stage II catkins could, be collected. Catkin length was measured for each stage of development for a minimum of 20 catkins. The length of five anthers dissected from the midpoint of the length of each of 20 catkins was also measured.

Microscopy. Portions of catkins selected for examination by scanning electron microscopy (SEM) were taken from the midpoint of the catkin length. Catkin sections and anthers prepared for SEM were fixed overnight at $4 \mathrm{C}$ in $4 \%$ glutaraldehyde, dehydrated in an ethanol series, and critical-point dried. Catkin sections for SEM were mounted on stubs, coated with goldpalladium, and examined with a Philips 505 SEM at $15 \mathrm{kV}$ (N. Amer. Philips Corp., Mahwa, N.J.). Anthers for light microscopy were infiltrated and embedded in resin (Spurr, 1969). Sections were stained with a mixture of $1 \%$ azure II buffered with $1 \%$ sodium borate $(1: 1)$.

Trichrome density determinations. Immediately on removal from the tree, catkins were placed into fixative containing acetic acid and 95\% ethanol (1:4) (McClintock, 1929). Catkins were removed from the mixture after a 24 -h fixation at room temperature and stored in $70 \%$ ethanol at 10C until analyzed. Five florets were dissected from the midpoint of the catkin length from each of eight catkins (two catkins from each of four trees), so that density determinations for each stage were based on 40 counts. The anthers were discarded and the bracts and bracteoles were placed in a drop of immersion oil with the outer surface of these floral parts oriented" away from the microscope slide. Trichomes were visible from fluorescence emissions when samples were examined with a Leitz Dialux 22 EB microscope equipped with a 3-A Ploemopak fluorescence vertical illuminator (LEICA, Wetzlar, Germany) with an 12/3 filter system consisting of a narrow band blue excitation filter (450 to 490 rim), a dichroic beam splitter (510 rim), and a barrier filter (515 $\mathrm{nm})$. The compound trichomes in a $0.63-\mathrm{mm}^{2}$ field of vision were counted in the center of the bract or bracteole.

\section{Results}

Catkin morphology. Five distinct stages of morphology for 'Desirable' and 'Stuart' could be differentiated based on bract position relative to the rachis, external visibility of bracteoles, anthers, and rachis, and anther color (Table 1). The angle between bracts and catkin rachis, and visibility of bracteoles, anthers, and rachis increased as catkins matured. Anthers developed a yellowish tinge just before dehiscence. The various stages of catkin morphology were reflected by an increase in length for both catkins and anthers (Fig. 1). The anthers and catkins for 'Desirable' and 'Stuart' had grown to $90 \%$ of their maximum length by Stage III. Length of anthers was maximum at Stage IV and decreased slightly at Stage V for both cultivars.

Morphological characteristics of catkins distinguishing each
Table 1. Morphological characterization of catkin development in 'Desirable' and 'Stuart' pecan.

\begin{tabular}{lccccc}
\hline \hline & \multicolumn{5}{c}{ Catkin characteristic } \\
\cline { 2 - 6 } $\begin{array}{l}\text { Catkin } \\
\text { stage }\end{array}$ & $\begin{array}{c}\text { Angle between } \\
\text { bract \& rachis }\left(^{\circ}\right)\end{array}$ & $\begin{array}{c}\text { Bracteole } \\
\text { visible }\end{array}$ & $\begin{array}{c}\text { Anther } \\
\text { visible }\end{array}$ & $\begin{array}{c}\text { Rachis } \\
\text { visible }\end{array}$ & $\begin{array}{c}\text { Anther } \\
\text { color }\end{array}$ \\
\hline I & 5 & No & No & No & Green \\
II & 10 & Yes & No & No & Green \\
III & 45 & Yes & No & No & Green \\
IV & 90 & Yes & Yes & Yes & Green \\
V & 90 & Yes & Yes & Yes & Yellow \\
\hline
\end{tabular}

Table 2. Morphological stages of pecan catkins sampled on each collection date in 1990.

\begin{tabular}{|c|c|c|c|c|c|}
\hline \multirow[b]{2}{*}{ Cultivar } & \multicolumn{5}{|c|}{ Catkin stage } \\
\hline & I & II & III & IV & $\mathrm{V}$ \\
\hline Desirable & 17 Apr. & $\begin{array}{l}17 \text { Apr. } \\
23 \text { Apr. } \\
26 \text { Apr. }\end{array}$ & $\begin{array}{l}23 \text { Apr. } \\
26 \text { Apr. } \\
30 \text { Apr. }\end{array}$ & $\begin{array}{l}30 \text { Apr. } \\
2 \text { May }\end{array}$ & 2 May \\
\hline Stuart & $\begin{array}{l}23 \text { Apr. } \\
26 \text { Apr. } \\
30 \text { Apr. } \\
2 \text { May }\end{array}$ & $\begin{array}{r}23 \text { Apr. } \\
26 \text { Apr. } \\
30 \text { Apr. } \\
2 \text { May }\end{array}$ & $\begin{array}{r}26 \text { Apr. } \\
30 \text { Apr. } \\
2 \text { May }\end{array}$ & $\begin{array}{r}26 \text { Apr. } \\
30 \text { Apr. } \\
2 \text { May } \\
4 \text { May }\end{array}$ & 4 May \\
\hline
\end{tabular}

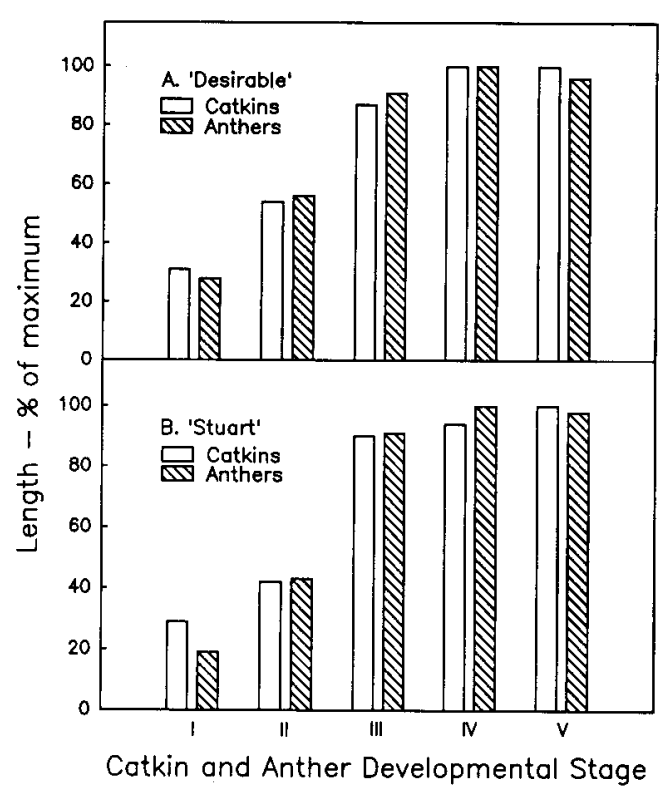

Fig. 1. Catkin and anther length at each developmental stage for two pecan cultivars.

stage were similar for 'Stuart' and 'Desirable'. Consequently, only 'Stuart' is represented. Traits associated with each stage were obvious from macroscopic examination but are more clearly illustrated by SEM. The major characteristic distinguishing Stage I catkins was that the bracts were so tightly appressed to the rachis that neither bracteoles nor anthers were externally visible (Fig. 2A). The anther was distinctly bilobate with connective tissue between the two lobes and a rudimentary filament at the base (Fig. 2B). Progressive differentiation of microsporangia in the lobes was observed (Fig. 2 C, D). The more immature anthers had lobes composed of a mass of undifferentiated tissue 

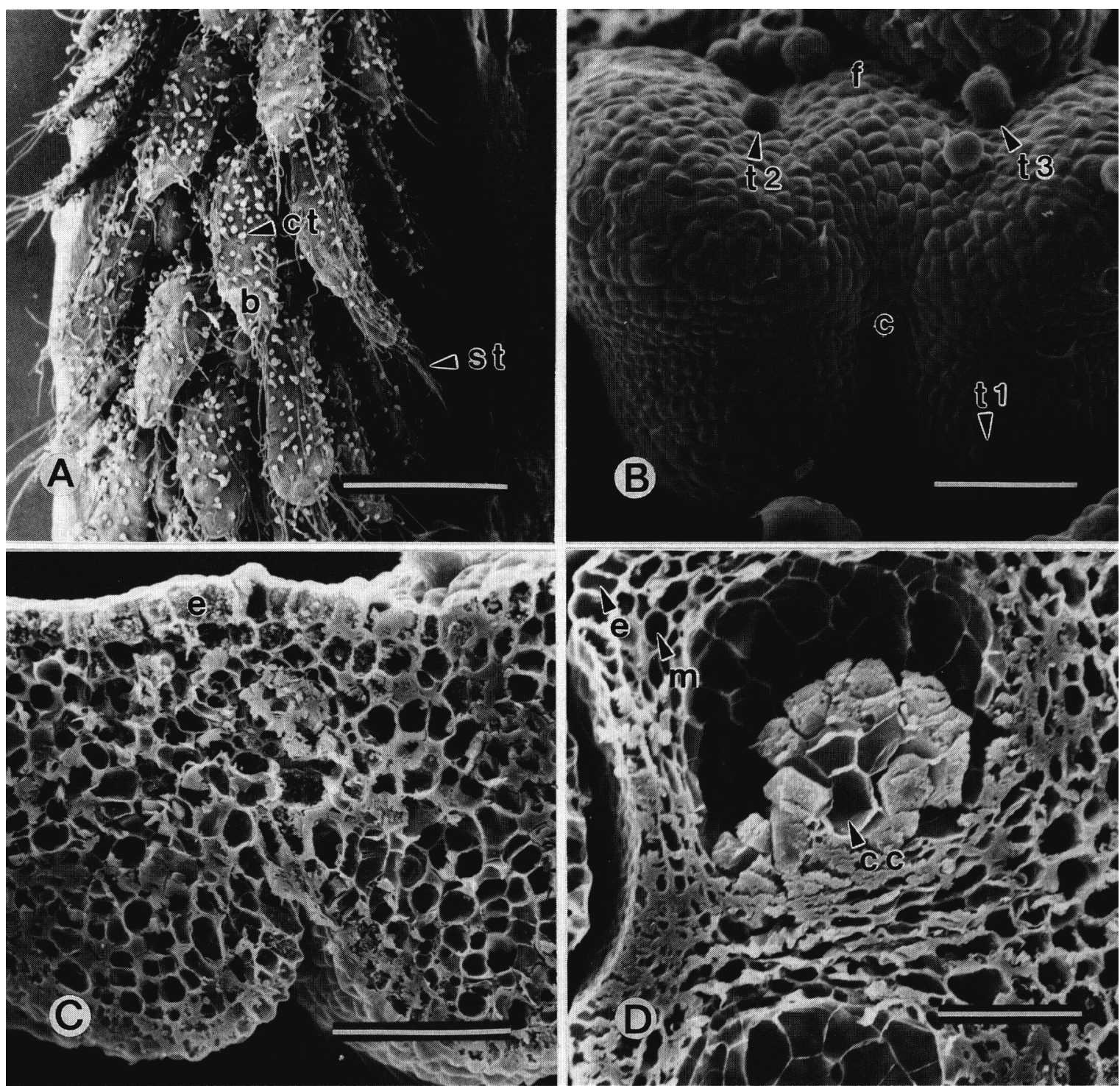

Fig. 2. Stage I 'Stuart' staminate inflorescence. (A) External morphology of catkin: $b=$ bract, ct $=$ compound trichomes, st $=$ simple trichomes. Bar $=1 \mathrm{~mm}$. (B) External morphology of bilobate anther: $\mathrm{f}=$ filament; $\mathrm{c}=$ connecting tissue between the two lobes; t1, t2, $\mathrm{t} 3$ = progressive stages in trichome differentiation. Bar $=0.05 \mathrm{~mm}$. (C) Cross section of anther with epidermis (e) covering mass of undifferentiated tissue. Bar $=0.05 \mathrm{~mm}$. (D) Two locules in cross section of anther: $\mathrm{e}=$ epidermis, $\mathrm{m}=$ middle layer, $\mathrm{cc}=$ central core. Bar $=0.1 \mathrm{~mm}$.

surrounded by a single layer of elongated epidermal cells (Fig. 2C). More developed anthers had a central core of thin-walled, multisided cells to form two locules in each lobe (Fig. 2D). The four or five cell layers between the epidermis and the central core of thin-walled cells could be identified only as middle layers because no structure characteristic of endothecial and tapetal cells had developed.

Bracteoles were externally visible on Stage II catkins (Fig. $3 \mathrm{~A})$. The bract had spread away from the catkin rachis creating an angle of $\approx 10^{\circ}$ between the bract and the rachis (Table 1 ). Anthers were more elongate, visually (Fig. 3B) and by length measurements (Fig. 1), and the filament supporting the anthers was more prominent (Fig. 3B) than in Stage I; however, the connective tissue between the two lobes was still very evident. In anther cross sections (Fig. 3C), the developing reproductive cells located in the center of each locule were surrounded by a single layer of elongated tapetal cells. A weak bond apparently existed between the tapetum and other anther wall tissues. The reproductive cells and the surrounding tapetal cells formed a free-standing column along the longitudinal axis of the anther in sections prepared for SEM (Fig. 3C). There were about four cells layers between the tapetum and the epidermis, and those closest to the tapetum appeared to be compressed. In contrast to 'Stuart', histogenesis in Stage II 'Desirable' catkins had proceeded to the point the tapetum cells had disintegrated as in Stage III 'Stuart' catkins.

Bracts were approaching a $45^{\circ}$ angle relative to the floral axis by Stage III of catkin morphology (Table 1). Anthers were still enveloped by the bracteoles and were not externally visible even though the bracts were spread away from the main floral axis (Fig. 4A). The connective tissue between the two anther lobes became more obscure (Fig. 4B) as anther size increased. The tapetal cells surrounding the reproductive cells had disintegrated and the middle layers were compressed (Fig. 4C). A layer of cells beneath the epidermis had developed distinct striations characteristic of wallthickening of mature endothecial cells (Fig. 4D). 

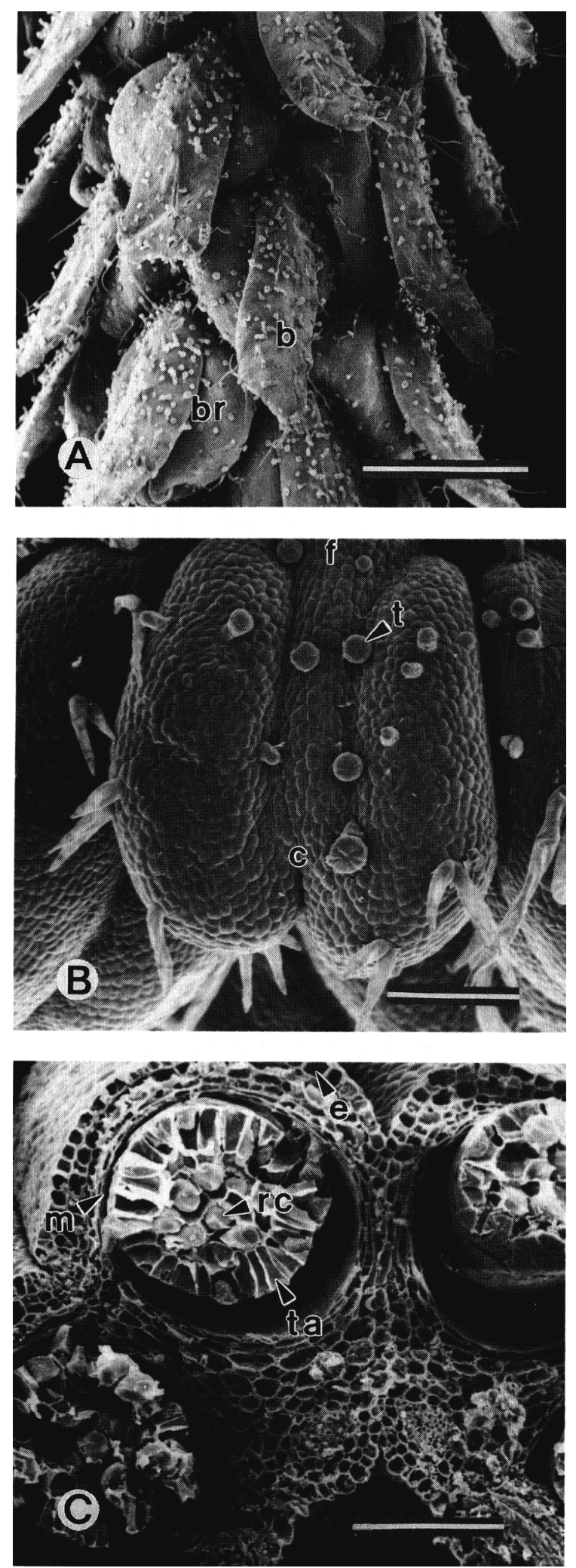

Fig. 3. Stage II 'Stuart' staminate inflorescence. (A) External morphology of catkin: $\mathrm{b}=$ bract, $\mathrm{br}=$ bracteole. Bar $=1 \mathrm{~mm}$. (B) External morphology of anther: $f=$ filament, $c=$ connecting tissue, $\mathrm{t}=$ trichome. Bar $=0.1 \mathrm{~mm}$. (C) Four locules in cross section of anther: $\mathrm{e}=$ epidermis, $\mathrm{m}=$ middle layer with arrow to indicate compressed layers, $\mathrm{ta}=$ tapetum, $\mathrm{rc}=$ reproductive cell. $\mathrm{Bar}=$ $0.1 \mathrm{~mm}$.
Stage IV and V catkins shared many similarities (Pigs. 5 A-D, 6 A-C). Anthers, bracts, and bracteoles were obvious by external examination (Figs. 5A and 6A, respectively) and the angle between the bract and the catkin rachis was $\approx 90^{\circ}$ (Table 1 ). The connective tissue between the anther lobes was not visible externally, but the suture that splits during anther dehiscence became conspicuous (Fig. 5B). The cells creating two locules in each anther lobe had disintegrated leaving the pollen grains randomly dispersed (Fig. 5C). The endothecium beneath the epidermis (Figs. 5C and 6C) had thickening along all walls except those abutting the epidermis (Fig. 6C). The major external morphological differences between these last two stages of catkin maturation were the yellowish tinge of anthers (Table 1) and the increased rachis visibility in Stage V compared with Stage IV catkins (Figs. 5A and 6A). Just before dehiscence in Stage V catkins, anthers developed a yellowish cast in contrast to the green anthers of earlier stages (Table 1). Pollen in both Stage IV and V catkins (Figs. 5D and 6B, respectively) had well-defined pores with a convex appearance. Pollen in Stage IV catkins had a membrane-like coating (Fig. 5D) that was greatly reduced in the mature pollen grain of Stage V catkins (Fig. 6B).

Trichomes on staminate floral parts. We categorized the trichomes occurring on the surface of the floral parts of pecan as either simple or compound (Fig. 7A) because no generally accepted morphological classification of the various trichome types exists (Behnke, 1984). Simple trichomes appeared to consist of only one cell type, creating a long, slender appendage. Compound trichomes had at least two cell types with one type forming a stalk and another forming a cap-like structure composed of two or more cells (Fig. 7B). Some compound trichomes seemed to be sessile when examined from the upper surface of the cap-like cells; however, a stalk consisting of at least one cell was characteristically present in lateral view (Fig. 7B).

A dense population of both simple and compound trichomes covered the outer bract surface in Stage I catkins with simple trichomes more concentrated near bract margins (Fig. 2A). Gently pulling the bract to the side. to expose the underlying bracteole demonstrated that bracteoles appeared to have a lower trichome density than bracts (Fig. 7A, Table 3). The density of trichomes decreased on bracteoles and bracts as catkins matured for both cultivars. 'Stuart' had a significantly higher density of trichomes on both bracts and bracteoles, regardless of maturation stage of the catkin, than did 'Desirable' (Table 3).

Compound trichomes on Stage I catkin bracteoles usually had a stalk consisting of at least one cell, whereas those on bracts in the same floret had up to four stalk cells (Fig. 7A). We examined trichomes on bracteoles of Stage III catkins to determine whether only one stalk cell might represent an early stage of trichome differentiation. The majority of compound trichomes on bracteoles of Stage III like Stage I catkins had only one stalk cell. Trichomes were restricted to the abaxial (outer) surface on both bracts and bracteoles.

Trichomes were more sparse on anthers (Figs. 2B, 3B, 4B, and $5 \mathrm{~B})$ than on bracts or bracteoles. Trichomes in several stages of development (Fig. 2B) were present on Stage I anthers. Trichomes appeared to originate as an enlargement of the epidermal cells (arrow 1) that assumed a spherical shape (arrow 2) to form a head cell followed by stalk formation (arrow 3) (Fig. 2B). By Stage III, compound trichomes were frequently in the regions of the anther wall in proximity to the connective tissue with some trichomes actually located on the connective tissue (Fig. 4B). 

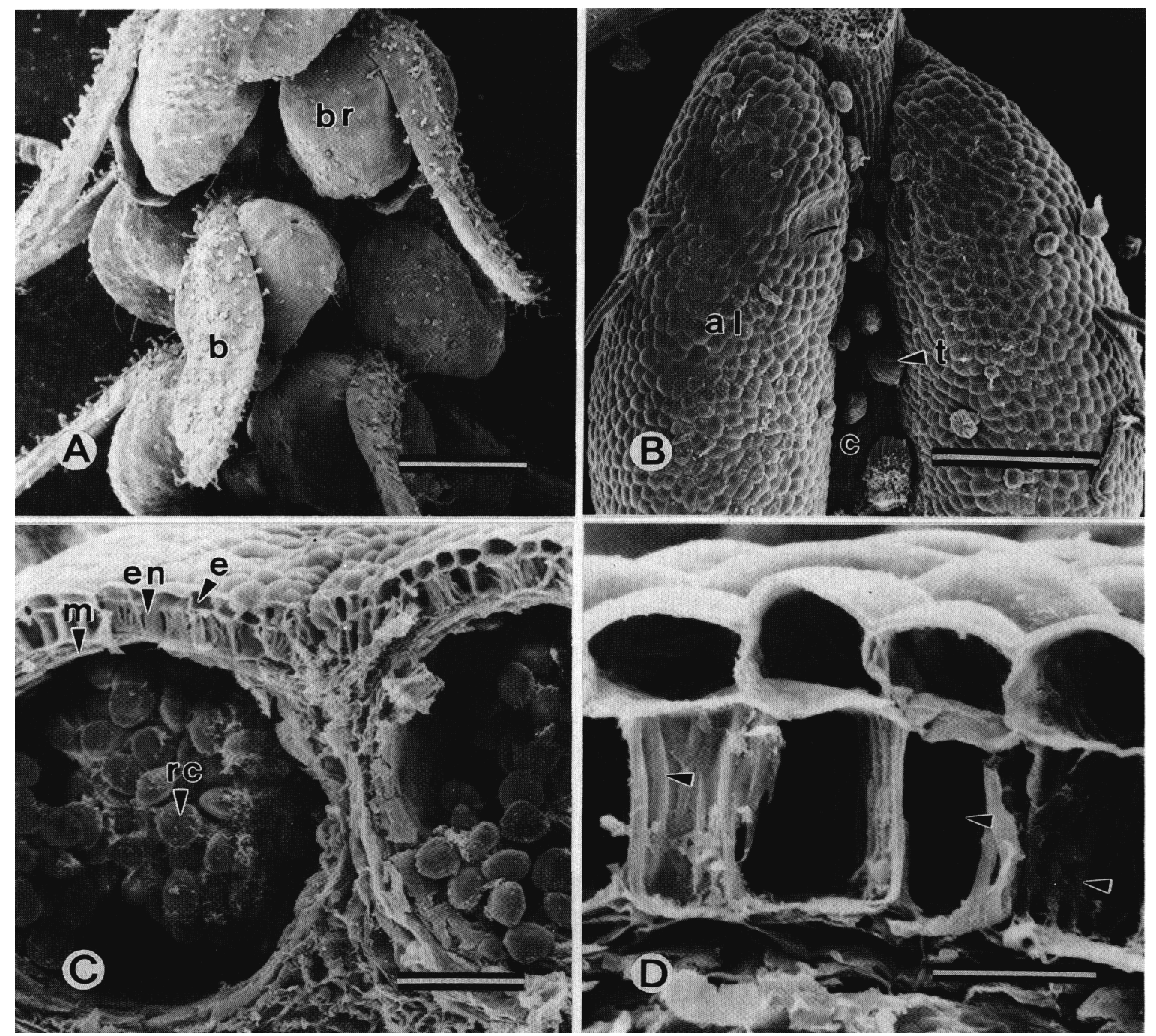

Fig. 4. Stage III 'Stuart' staminate inflorescence. (A) External morphology of catkin: $\mathrm{b}=$ bract, br $=$ bracteole. Bar $=1 \mathrm{~mm}$. (B) External morphology of anther: al $=$ anther lobe, $\mathrm{c}=$ connecting tissue, $\mathrm{t}=$ trichome. Bar $=0.2 \mathrm{~mm}$. (C) Two locules in cross section of anther: $\mathrm{e}=$ epidermis, $\mathrm{m}=$ middle layer with arrow to indicate compressed layers, en $=$ endothecium, $\mathrm{rc}=$ reproductive cell. $\mathrm{Bar}=0.1 \mathrm{~mm}$. (D) Cross section of anther wall locule with striations in endothecial cell walls (arrow). Bar $=25 \mu \mathrm{m}$.

\section{Discussion}

Woodroof's (1930) description of the tissues constituting the anther wall in pecan was ambiguous as he apparently equated the endothecium with the tapetum. We conclude from the results of the current investigation that the anther wall of pecan is typical of Juglans (Luza and Polito, 1988) and other angiosperms (Esau, 1965) consisting of an epidermis, endothecium, middle layers, and tapetum (Esau, 1965). The single-layered epidermal cells remained intact and were not sloughed off at maturity, as occurs in some plant species (Bhandari, 1984). A thick-walled endothecium interior to the epidermis was evident in anthers from Stage III, IV, and V catkins. The endothecium aids in anther dehiscence and pollen dispersal (Heslop-Harrison, 1972); hence, differentiation of this tissue in the late stages of catkin maturation would be expected. Adjacent to the endothecium was tissue of about three cell layers termed the middle layers. The most interior layer of the anther wall was the tapetum that surrounded the reproductive cells. The connection between the tapetum and the middle layer was weakened, prob- ably due to the dissolution of the plasmodesmata connecting these two wall components (Heslop-Harrison, 1972). Tapetal cells provide nutrients to the developing reproductive cells (Heslop-Harrison, 1972). By Stage IV, the tapetum had disintegrated, the reproductive cells had matured to pollen grains, and the middle layers had become compressed to a thin layer. Woodroof (1930) may have confused the tapetum and endothecium because the distinctive characteristics of these two tissues were most obvious at separate catkin stages. The tapetum had disintegrated by the time the endothecium had developed distinctive wall thickening.

Catkins had reached $90 \%$ of their maximum length by Stage III. Extensive internal changes occur within anthers between Stages III and V. Only 10 days elapse from the time catkins reach $90 \%$ of their maximum elongation until anther dehiscence, as extrapolated from data reported by Davis and Sparks (1972). Hence, substantial anther development occurs in a short time relative to the year required from initiation to dehiscence of anthers. 

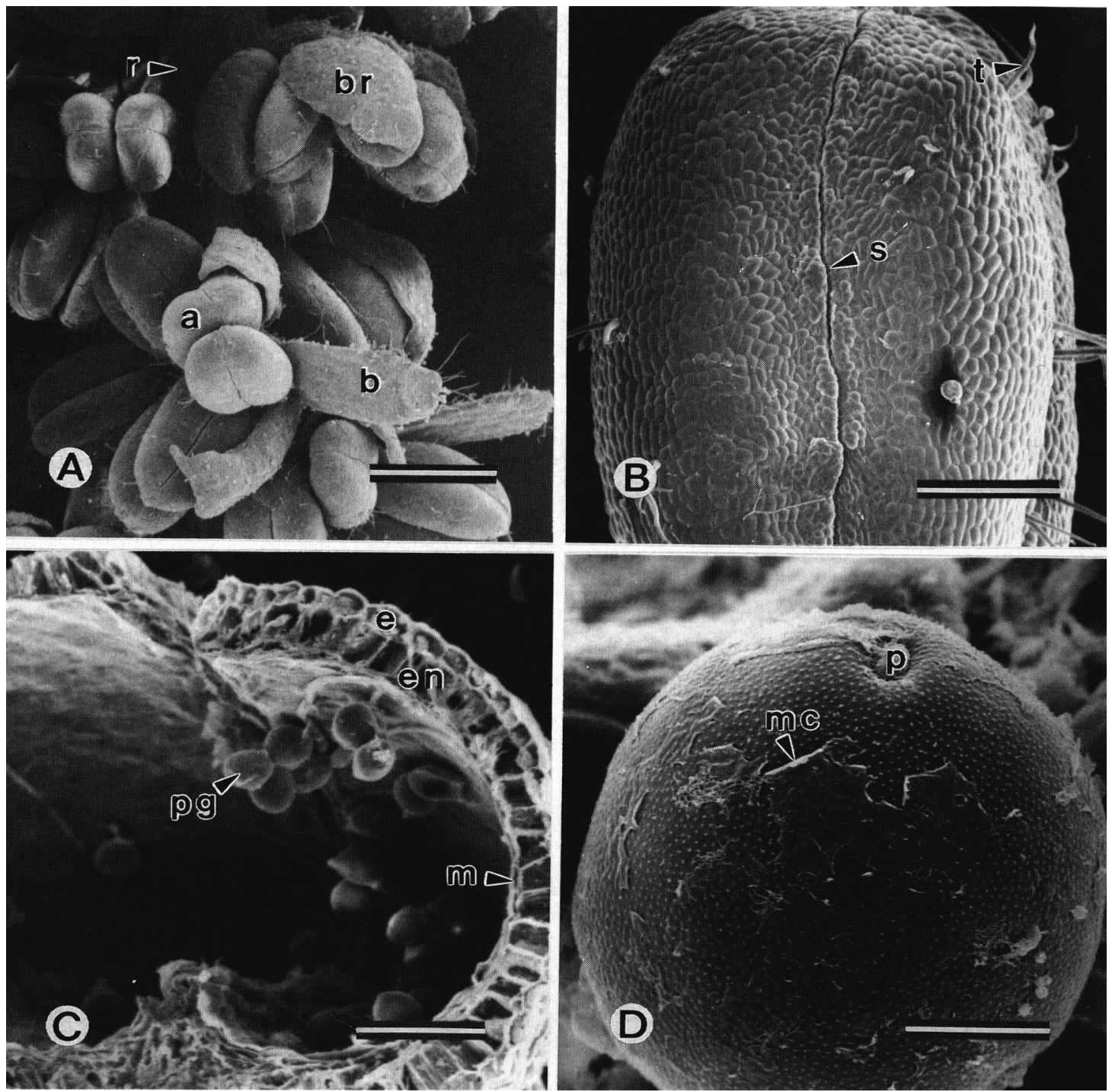

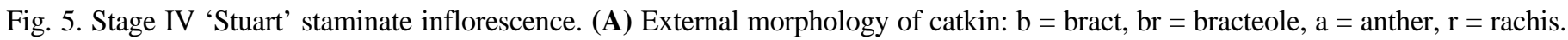
Bar $=2 \mathrm{~mm}$. (B) External morphology of anther: $\mathrm{s}=$ suture. Bar $=0.25 \mathrm{~mm}$. (C) Cross section of an anther lobe; e $=$ epidermis, en $=$ endothecium, $\mathrm{pg}=$ pollen grain, $\mathrm{m}=$ compressed middle layers. Bar $=0.1 \mathrm{~mm}$. (D) Pollen grain: $\mathrm{p}=$ pore, $\mathrm{mc}=$ membrane-like coating. Bar $=10 \mu \mathrm{m}$.

Trichomes were a common structural feature of the staminate floral parts. The density of compound trichomes decreased with proximity of the floral part to the rachis; i.e., there were more trichomes on bracts than on bracteoles, and more on bracteoles than on anthers. Several stages of trichome development were present on anthers in Stage I catkins with trichomes appearing as outgrowths of the epidermal cells. In contrast, trichome development was apparently complete on Stage I bracts and bracteoles because they appeared the same as in Stage III. This phenomenon may be related to the age of the floral parts, in that the bracts and bracteoles were initiated before anthers (Wetzstein and Sparks, 1984; Woodroof, 1930). The density of trichomes on bracts and bracteoles decreased with expansion of the organs.

The slight decrease in anther size during Stage V probably resulted from their desiccation in preparation for dehiscence. Lily anthers also decrease slightly in length as the pollen grains reach maturity (Linskens, 1956). Judging from the convex appearance of the pecan pollen pore in Stage V anthers (Fig. 6D), the pecan pollen was still hydrated while within the anther. Apparently, pecan pollen does not dehydrate until actual anther dehiscence. As pecan pollen becomes exposed to atmospheric conditions exterior to the anther, dehydration may be rapid. We have previously demonstrated that dehisced pecan pollen responds within minutes to environmental conditions of temperature and relative humidity (Yates and Sparks, 1989). Similarly, Payne (1981) emphasized that changes of size and moisture content of pollen grains occur principally at the stigma surface when a grain, arriving dry, absorbs moisture before germination with the opposite condition occuring as the anther dehisces. The tapetal fluids surrounding the pollen grain evaporate and the previously turgid grain dries on exposure to the atmosphere.

A membrane-like coating appeared on pollen grains when the bract was at a $90^{\circ}$ angle to the main floral axis and the anthers 

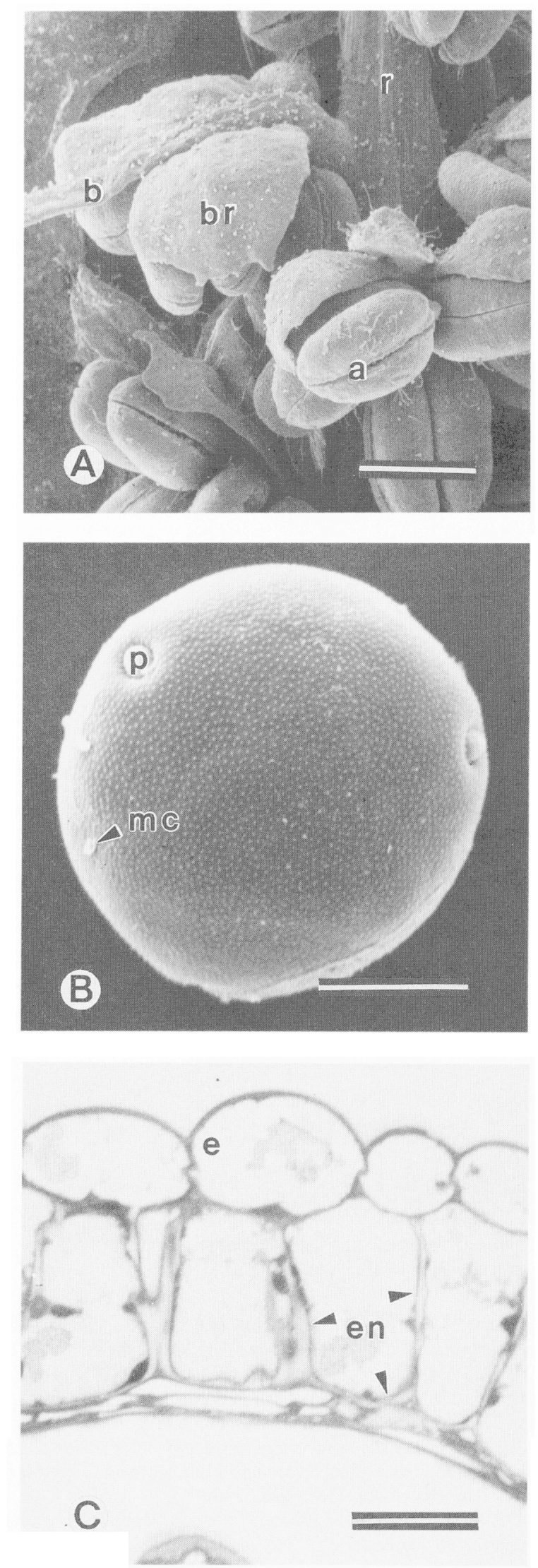

Fig. 6. Stage V 'Stuart' staminate inflorescence. (A) External morphology of catkin: $\mathrm{b}=$ bract, $\mathrm{br}=$ bracteole, $\mathrm{a}=$ anther, $\mathrm{r}=$ rachis. Bar $=2 \mathrm{~mm}$. (B) Pollen grain: $\mathrm{p}=$ pore, $\mathrm{mc}=$ membranelike coating. Bar $=10 \mu \mathrm{m}$. (C) Fixed cross section of anther wall: $\mathrm{e}=$ epidermis. $\mathrm{en}=$ endothecial cells. arrows $=$ thickened cell wall. $\mathrm{Bar}=25 \mu \mathrm{m}$
Table 3. Compound trichome densities on staminate floral parts. ${ }^{2}$

\begin{tabular}{lclr}
\hline \hline & & \multicolumn{2}{c}{ Catkin stage } \\
Cultivar & Floral part & I & V \\
\hline \multirow{2}{*}{ Desirable } & & \multicolumn{2}{c}{ Trichome density $\left(\mathbf{m m}^{2}\right)$} \\
& Bracts & 31.8 & 9.5 \\
Stuart & Bracteoles & 19.8 & 7.9 \\
& Bracts & 38.3 & 20.2 \\
& Bracteoles & 26.2 & 11.4 \\
\hline
\end{tabular}

${ }^{2}$ Trichorne densities on bracts vs. bracteoles within catkin Stage I and within catkin Stage V for each cultivar were significantly different, paired $t$ test. $P \leq 0.05$. Trichome densities on bracts between cultivars at Stage I and at Stage V and on bracteoles between cultivars at Stage $\mathrm{I}$ and at Stage $\mathrm{V}$ were significantly different, $t$ test. $P \leq 0.05$.

were still green (Stage IV) but had diminished by the time the anthers developed a yellowish tinge just before dehiscence (Stage V). Surface coatings have been described on the pollen grains from many genera of dicots and have been associated with the mode of pollen dispersal (Knox, 1984). The pollen coat in entomophilous species is present even when the pollen is released from the anther and serves to link the pollen grains together. In contrast, the pollen coat of anemophilous species remains in the anther locule at pollen dispersal. The absence of this coating on the mature pecan pollen grain is consistent with the anemophilous dispersal mechanism operative in pecan. In addition, the absence of the coating on the mature pecan pollen grain may account for the yellowish cast apparent on external examination of pecan anthers just before dehiscence. Only two layers of the anther wall, the epidermis and the endothecium, remain at pollen dispersal. Light reflected by the yellow pigments of the pollen grain without the pollen coat can penetrate the thin-walled anther. Thus, the external green appearance of the anther is diminished.

In summary, changes in external morphological characteristics of catkins indicate cellular specialization occurring within the anthers. Gross morphological markers during catkin maturation can be used to gauge cellular specialization within the anther. The rate and extent of growth of a field-grown plant, such as a pecan tree, can be subject to variation by seasonal environmental and climatic conditions (Sparks, 1988, 1989). Even within the same season and under the same climatic conditions, extreme variability exists over time in the development of the pecan staminate inflorescence. The variability was demonstrated by the collection of specific catkin stages on several dates and of several stages on any given date. The variability of catkin development within and among given dates illustrates the need for well-defined morphological markers, rather than a time sequence, to judge maturation stages. In addition, absolute size of structures, such as anthers and catkins, may not provide reliable criteria for staging cellular events because of the possibility of variability of these organs with tree vigor and age (Sparks, 1988). Staging catkin development by a combination of external morphological characteristics, including the angle between the bract and rachis, bracteole, anther and rachis visibility, and anther color can provide markers for histogenesis.

\section{Literature Cited}

Behnke, H.D. 1984. Plant trichomes-Structure and ultrastructure: General terminology, taxonomic applications, and aspects of trichome-bacteria interaction in leaf tips of Dioscorea, p. 1-21. In: E. Rodriguez, P.L. Healey, and I. Mehta (eds.). Biology and chemistry of plant trichomes. Plenum, New York. 

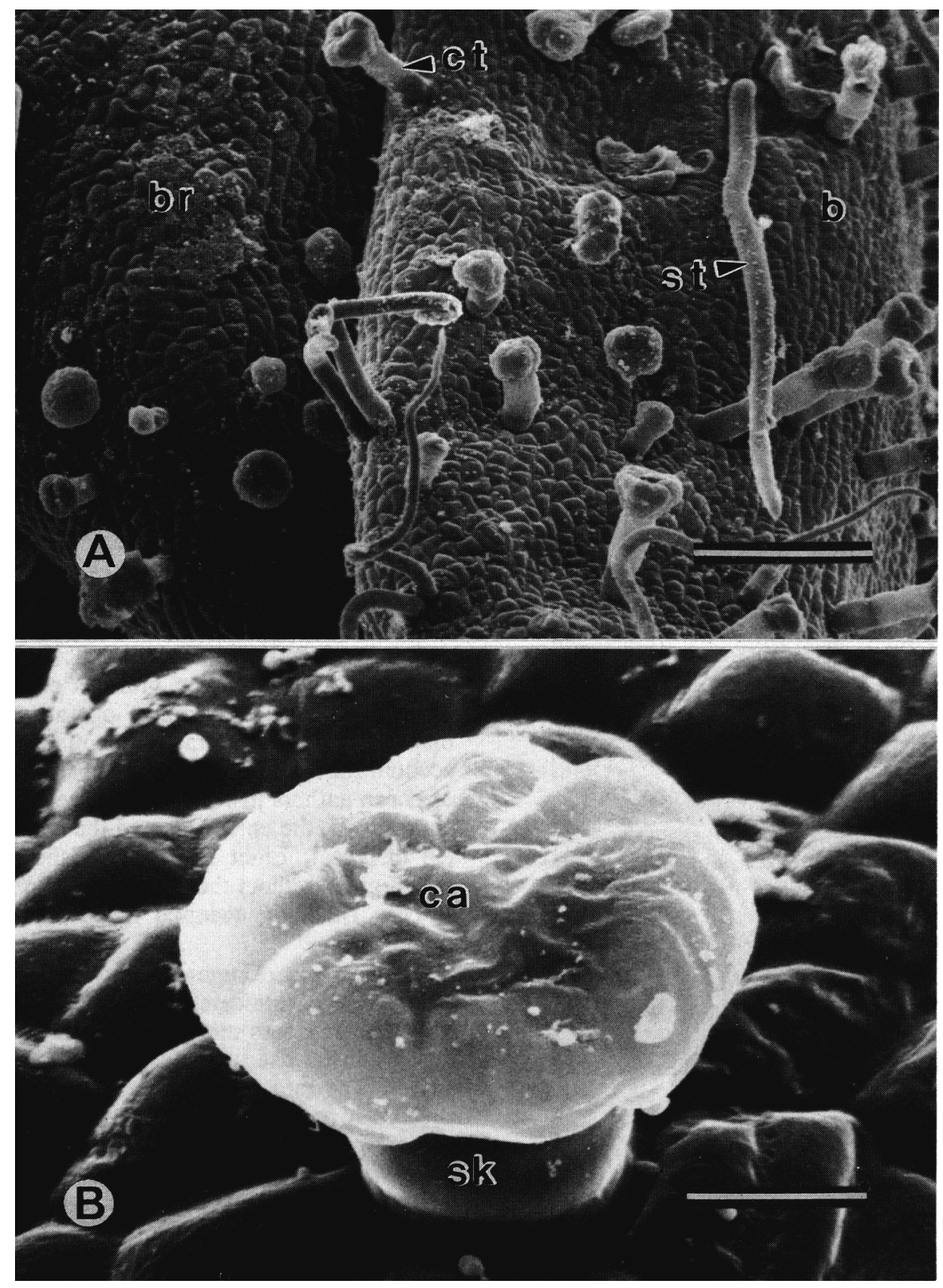

Fig. 7. Trichomes on pecan staminate floral parts. (A) Stage I bract and bracteole: $\mathrm{b}=$ bract, br $=$ bracteole, st $=$ simple trichome, ct $=$ compound trichome. Bar $=0.1 \mathrm{~mm}$. (B) Side view of compound gland: $\mathrm{ca}=\mathrm{cap}$, sk $=$ stalk. Bar $=10 \mu \mathrm{m}$.

Bhandari, N.N. 1984. The microsporangium, p. 53-121. In: B.M. Johri (ed.). Embryology of angiosperms. Springer-Verlag, New York. Cope, M. and I.E. Yates. 1987. Relationship between floret differentiation and microsporogenesis in pecan. HortScience 22:724 (Abstr.)

Davis, J.T. and D. Sparks. 1971. Assimilation of ${ }^{14} \mathrm{CO}_{2}$ by catkins of Carya illinoensis and apparent translocation to the pollen. Amer. J. Bot. 58:932-938.

Esau, K. 1965. Plant anatomy. 2nd ed. Wiley, New York.

Haulik, T.K. 1985. Pomological, morphological and anatomical study of the pecan [Carya illinoensis (Wang.) K. Koch]. PhD Diss., Univ. Pretoria, Pretoria, S. Afr.

Haulik, T.K. and L.C. Holtzhausen. 1988. Anatomy of staminate flower ontogeny of the pecan as determined by scanning electron microscopy. S. Afr. J. Plant Soil 5:205-208.

Heslop-Harrison, J. 1972. Sexuality of angiosperms, p. 133-289. In:
F.C. Steward (ed.). Plant physiology-A treatise. VIC: Physiology of development: From seeds to sexuality. Academic, New York.

Knox, R.B. 1984. The pollen grain, p. 197-271. In: B.M. Johri (ed.). Embryology of angiosperms. Springer-Verlag, New York.

Linskens, H.F. 1956. Pysiologische Untersuchungen zur Reifeteilung. I. Mitteilung. Uber die Anderung einiger physiologischen Zustandgrössen während der Pollenmeiose und Pollenentwicklung von Lilium henri. Ber. Deut. Bot. Ges. 69:353-360.

Luza, J.G. and V.S. Polito. 1988. Microsporogenesis and anther differentiation in Juglans regia L.: A developmental basis for heterodichogamy in walnut. Bot. Gaz. 149:30-36.

Maximos, S.E., A.Z. Bondok, M.A. Salama, S.M. Habib, and N.F. Youssuf. 1984. Histological studies on pistillate and staminate floral bud's differentiation of "Curtis" pecan. Ann. Agr. Sci., Faculty Agr., Ain-Shams Univ., Cairo 29:1015-1025. 
McClintock, B. 1929. A method for making aceto-carmin smears permanent. Stain Technol. 4:53-56.

Nakayama, R.M. 1967. Pecan variety characteristics. N.M. Agr. Expt. Sta. Bul. 520

Payne, W.W. 1981. Structure and function in angiosperm pollen wall evolution. Rev. of Palaeobotany and Palynology 35:39-59.

Rogers, S.O. and R.S. Quatrano. 1983. Morphological staging of wheat caryopsis development. Amer. J. Bet. 70:308-311.

Sparks, D. 1988. Effect of shoot vigor on distillate flower production and abortion in 'Stuart' pecan. HortScience 23:570-571.

Sparks, D. 1989. Predicting nut maturity of the pecan from heat units. HortScience 24:454-455.

Spurr, A.R. 1969. A low-viscosity epoxy resin embedding medium for electron microscopy. J. Ultrastructure Res. 26:31-43.
Wetzstein, H.Y. and D. Sparks, 1984. The morpholog of staminate flower differentation in pecan. J. Amer. Soc. Hort. Sci. 109:245252.

Wheatley, W. G., A.A. Marsolais, and K.J. Kasha. 1986. Microspore growth and anther staging in barley anther culture. Plant Cell Rpt. 5:47-49.

Woodroof, J.G. 1930. Studies of the staminate inflorescence and pollen of Hicoria pecan. J. Agr. Res. 40:1059-1104.

Yates, I.E. and D. Sparks. 1989. Hydration and temperature influence in vitro germination of pecan pollen. J. Amer. Soc. Hort. Sci. 114:599605.

Yates, I. E., B. Wood, and J.L. Giles. 1986. Relationship of catkin and pollen development in pecan. HortScience 21:936. (Abstr.) 